\title{
Khaoula Trad
}

\section{The Impact of Maghribi Hadīth Commentaries on the Mashriq}

\section{Introduction}

Within twenty years of the prophet Muhammad's death, Islam fanned out westward, ${ }^{1}$ beginning with Ifrīqiya ${ }^{2}$ until reaching the Iberian Peninsula in $92 \mathrm{H} /$ 711 CE. ${ }^{3}$ From Kairouan to Fez and on to Córdoba, these lands were to remain strongly interconnected, despite the changes of dynasties and the historical events that would push the two shores of the western Mediterranean to confront one another ${ }^{4}$ and at times to each consider the other part as the enemy. ${ }^{5} \mathrm{Al}-\mathrm{Ma}$ ghrib al-ifrīqi and al-Maghrib al-andalusi ${ }^{6}$ formed a nucleus of a geographical, social, cultural and religious convergence. The conquest was not only a territorial and political expansion, but also a specifically religious and ideological one, and so the spread of Islam brought with it the development and flourishing of the Islamic sciences, including 'ulüm al-hadìth and in particular the genre of hadith commentaries.

In this context, the present contribution intends to shed light on how hadith collections were introduced into the Islamic West, how they were received, how Maghribi scholars dealt with them, and, accordingly, how the Maghrib came to be considered as dār hadith. In addition, I will dedicate a section to the leadership of the Maghrib vis-à-vis the hadith literature dealing with commentaries. As indicated in the title, the central purpose of this study is to highlight the importance of Maghribi hadith commentaries and their impact on the Mashriq. I will take the

1 Ibn 'Abd al-Ḥakam, Futūh (1964), 28-29.

2 Present-day Tunisia, western Libya and eastern Algeria.

3 Lévi-Provençal 1938, 14; Chalmeta 1994, 133. A detailed study on the date of the conquest is available on Sánchez Albornoz 1945, 52-105.

4 Marín 1985, 45.

5 They were explicitly called al-jāratayn al-'aduwwatayn ("the enemy neighbors"). See Nūr alDīn 1989, 104.

6 See below.

Note: This paper was presented at the international conference "The Maghrib in the Mashriq", which took place on 20-21 December 2018.

D Open Access. (C) 2021 Khaoula Trad, published by De Gruyter. (c) BY-NC-ND This work is licensed under the Creative Commons Attribution-NonCommercial-NoDerivatives 4.0 International License. 
Ṣaḥị̣ of Abū al-Ḥusayn 'Asākir al-Dīn Muslim b. al-Ḥajjāj (d. 261 H/875 CE) as a case study, and will attempt to demonstrate its importance through subsequent Maghribi works that were based on it. As for the impact of Maghribi hadith commentaries on Mashriqi scholars, I will focus on two commentaries: Ikmāl alMu'lim fì sharh Ṣaḥị̣ Muslim by Qāọī 'Iyāḍ (d. 544 H/1149 CE) and al-Mufhim limā ashkala min talkhịs kitāb Muslim by Abū al-'Abbās al-Qurțubī (d. 656 H/ $1258 \mathrm{CE})$.

\section{Contextualization}

\subsection{The Maghrib and the Mashriq}

Geographers and historians differed about the definition of the term al-Maghrib, ascribing to it diverse geographical dimensions. ${ }^{7}$ Literally, al-Maghrib (the West) is the opposite of al-Mashriq (the East). From its original meaning indicating the place where the sun sets, ${ }^{8}$ it came to designate, during the period of al-fitna alkubrā (35-41 H/656-661 CE), the western part of the Islamic world, which at that time comprised Egypt, its surroundings and the Levant. ${ }^{9}$ As the Islamic Empire continued to expand westward and consolidate its hold on North Africa, the Islamic West, now regarded as extending from Barqa in present-day Libya through to the Atlantic, came to be considered as a homogeneous cultural entity. There was, however, the ongoing question of whether or not al-Andalus was a part of the Maghrib or not. Al-Idrīsī (d. ca. 560 H/1164-5 CE), for example, describes alAndalus as being very close to the Maghrib, and representing a natural extension of it that influences and is influenced by the events happening there. ${ }^{10} \mathrm{By}$ contrast, in Yāqūt al-Hamawī's (d. 626 H/1229 CE) Mu'jam al-buldān, ${ }^{11}$ the Maghrib is taken to comprise al-Andalus and the territories between Milyāna ${ }^{12}$ and the Sūs mountains. ${ }^{13}$ In al-Miqbās fi akhbār al-Maghrib wa-Fās - attributed to Abū

7 See the studies by Giovanna Calasso and by Víctor de Castro included in this same volume.

8 Sa'dūn 1988, 19.

9 Mu'nis 2003, 24; Laqbāl 1951, 14.

10 Al-Idrīsī, Nuzhat al-mushtā $q$ (1989), 2: 525.

11 Yāqūt al-Ḥamawī, Mu 'jam al-buldān (1988), 5: 161.

12 A town in north-western Algeria, considered as the border of Ifrīqiya.

13 It is located in the Sūs, which is a region in mid-southern Morocco, bordered by the Grand Atlas Mountains to the north, by the Anti-Atlas to the east and south, and by the Atlantic Ocean to the west. 
Marwān 'Abd al-Malik b. Mūsā al-Warrāq (alive in 555 H/1160 CE) ${ }^{14}$ - it includes all the lands from the banks of the Nile in Alexandria up to Salé. ${ }^{15}$ However, despite these differing views, the majority of geographers and historians reached the general consensus that al-Maghrib referred to "the Islamic lands [that] extended from western Egypt until the Atlantic Ocean, including al-Andalus. Considering the existence of al-Maghrib al-ifrīqi and al-Maghrib al-andalusī, the term Maghrib or Maghāriba includes, indeed, al-Andalus and its inhabitants". ${ }^{16}$

As for al-Mashriq, it begins in Egypt and extends through the Levant (bilād al-shām), the Arabian peninsula (al-jazira al-'arabiyya), upper Mesopotamia (aljazīra al-furātiyya), Iraq, Khorasan, Transoxiana (bilād mā warā'a al-nahr), Persia (bilād Fāris), iqlīm al-Jibāl, ${ }^{17}$ Sindh, Sistan (Sijistān) and Daylam (bilād aldaylam).$^{18}$ Although Egypt is situated in the middle - thus playing the role of a connecting boundary, and sharing cultural, political, historical and ethnic characteristics with both parts - it is generally considered to belong to the Mashriq.

\subsection{The introduction of hadith literature in the Maghrib}

The 2nd/8th century is held to mark the spread of Mālikism out of its original birthplace in Medina, where its eponymous founder Mālik b. Anas (d. 179 H/ 795 CE) lived and taught, and Egypt was the first province outside the Arabian Peninsula to receive this doctrine. ${ }^{19}$ By the end of the century, the Mālikī legal school in Alexandria was established, ${ }^{20}$ which made a significant contribution to the spread of Mālikism into the West. Alexandria was the principal gateway to

14 Ibn 'Idhārī, al-Bayān (2013), 1: 26.

15 A town in north-western Morocco.

16 Al-'Abbādī 1978, 10.

17 Ibn Ḥawqal, Șūrat al-arḍ (1992), 304.

18 Al-Jabrānī 2016, 42.

19 Al-Jaydī 1987, 19.

20 Due to its strategic location as a nexus between the Maghrib and the Mashriq. See Ibn 'Ațā'illāh, al-Ḥikam (1984), 5. In addition, 'Abd al-Rahīm b. Khālid b. Yazīd al-Jumahịi (d. 163 H/ $780 \mathrm{CE}$ ) - who was the first to introduce the "issues” ( $m a s \bar{a} ’ i l)$ of Mālik's madhhab into Egypt was from Alexandria, as were Zayn b. Shu'ayb b. Kurayb al-Ma'āfirī (d. 184 H/801 CE) and Țulayb b. Kāmil al-Lakhmī (d. 173 H/790 CE). Likewise, Ibn al-Qāsim (d. 191 H/807 CE), Ashhab (d. 203 H/819 CE) and 'Abd Allāh Ibn 'Abd al-Ḥakam (d. 214 H/830 CE) taught there before travelling to Medina to meet Mālik in order to certify what they had learned or to obtain the honour of isnād superiority (nayl sharaf 'ulūw al-isnād); e.g. Ibn al-Qāsim asserts that he knew all there was to know about Mālik and his madhhab before meeting him (mā kharajtu li-Mālik illā wa-anā 'ālim bi-qawlihi). See Qāọī 'Iyāọ, Tartīb al-madārik (1983), 3: 56, 54-61. 
Ifrīqiya and would afterward become the base for Maghribi scholars during their rihla fi talab al- 'ilm, or journey in search of knowledge, which was often carried out in combination with the hajj. ${ }^{21}$ After Medina and Alexandria, Kairouan constituted the third major Mālikī hub. At the beginning of the 3rd/9th century, Mālikism had become the main madhhab in the Maghrib, together with

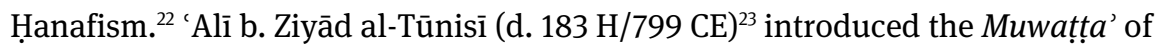
Mālik in Ifrīqiya ${ }^{24}$ before 161 H/777 CE ${ }^{25}$ and al-Ghāzī b. Qays (d. 199 H/815 CE) later brought it to Córdoba. ${ }^{26}$ Being the second seminal book introduced in the Maghrib after the Qur'ān, the Muwatța' contributed substantially to the development and establishment of Mālikī law in the region. The process of reception was accompanied by that of reflection and adaptation; in Ben 'Ashūr's words:

Exegesis, thematization, the definitive choice between the solutions proposed and the shift from proposed doctrine to declarations of uniform law, the establishment of mechanisms for memorization and automated thought - all of this belongs to the Maghrib. ${ }^{27}$

Some scholars started to combine their interest in the study of Mālikī furū' legal treatises such as the Mudawwana with that of hadith, as did Muhammad Ibn Waḍḍāh (d. 287 H/897 CE). His contemporary Baqī b. Makhlad (d. 276 H/889 CE) went as a step further, as he did not follow the Mālikī legal school. After some thirty-five years of long journeys in search of knowledge, Baqī b. Makhlad introduced the Muṣannaf of Ibn Abī Shayba (d. 235 H/850 CE) in al-Andalus. ${ }^{28}$ His hadìth-oriented outlook elicited the strong opposition of some Mālikī jurists, ${ }^{29}$ but

21 The journey in search of knowledge was a requirement for everyone who aspired to strengthen and widen their skills, to meet great authorities and learn from them. Traditionally, the rihla was an eastward journey because it was associated with the pilgrimage to Mecca.

22 Two schools of thought preceded the Mālikī madhhab in the Maghrib, those of al-Thawrī (d. $161 \mathrm{H} / 777 \mathrm{CE}$ ) and al-Awzā'i (d. 157 H/774 CE), but they quickly disappeared, making way for the consolidation of Mālikism.

23 Also known as al-Imām al-Ṭarābulusī. He was a companion of Mālik and the teacher of Asad b. al-Furāt (d. 213 H/828 CE) and Imām Saḥnūn (d. 240 H/854 CE).

24 Specifically in Kairouan. See al-Sharîf 1999, 34.

25 Ghrab 1992, 170-171.

26 Al-Ḥamīdī 2008, 313, maintains that Ziyād b. 'Abd al-Raḥmān al-Lakhmī (d. 193 H/809 CE), known as Shabțūn, was the first to introduce the Mālikī school of law in al-Andalus and accordingly the dissemination of the doctrine is attributed to him. More details on this topic can be found in Idris 1967, 397-414; Fierro 1989, 68-93; Carmona 2005.

27 Ben 'Ashūr 1992, 85.

28 Ibn al-Faradīi, Ta’rīkh (2008), 1: 145.

29 Așbagh b. Khalīl (d. 273 H/988 CE) prevented Qāsim b. Aṣbagh from listening to Baqī b. Makhlad and had forbidden the disciples from being taught by ahl al-hadith. He went so far as to assert 
Baqī b. Makhlad was able to survive persecution and had many students who attended his lessons. Thanks to him and to Ibn Waḍdāḥ, al-Andalus came to be considered dār hadìth.

Gradually, the collections of hadith spread across the Maghrib. The Sunan of Abū Dāwūd (d. 275 H/888 CE) occupied the first place and captured the attention of the Cordoban jurists. ${ }^{30}$ As regards al-Andalus, the Sunan of Abū Dāwūd (d. 275 H/888 CE) was introduced by, among others, Ahmad b. Duhaym b. Khalīl b. 'Abd al-Jabbār b. Ḥarb al-Qurțubī (278-338 H/891-949 CE). ${ }^{31}$ Abū Bakr Muḥammad b. Mu'āwiya b. 'Abd al-Raḥmān (d. 358 H/971 CE), known as Ibn alAhmar, introduced the Sunan of al-Nasā'ī (d. 303 H/915 CE) into al-Andalus around $350 \mathrm{H} / 963 \mathrm{CE} .{ }^{32}$ The Jāmi of al-Tirmidhī (d. $279 \mathrm{H} / 892 \mathrm{CE}$ ) came next, ${ }^{33}$ gaining more popularity in al-Andalus than in Ifrīqiya, where it was replaced by Muslim's Șahīh. It was followed by al-Dāraquṭnīs (d. 385 H/995 CE) Sunan and the Musnad of Ibn Hanbal (d. 241 H/855 CE), while Ibn Māja's (d. 273 H/886 CE) Sunan did not attract scholarly attention in the Maghrib. ${ }^{34}$ Thus, the 4th/10th century marks the beginning of the heyday of 'ulüm al-ḥadith in al-Andalus, where scholars became increasingly well-versed in this discipline as "the opposition between ahl al-ra'y and ahl al-hadith diminished". ${ }^{35}$

that he would rather be buried with a pig's head than with the Muṣannaf of Ibn Abī Shayba. See al-Dhahabī, Siyar (1992), 13: 202. See also Talīdī 1995, 24.

30 Ibn Khayr, Fahrasa (1998), 91.

31 Robson 1952, 584.

32 He set out on his rihla in 295 H/907 CE, and saw al-Nasā'î in 297 H/909 CE in Fustat. From there he went on to Baghdad, Basra and India. When he came back to al-Andalus, he brought with him the Sunan and taught it to Abū Muḥammad 'Abd Allāh b. Rabī' b. Bannūsh al-Tamīmī (d. 415 H/1027 CE). See Ibn Khayr, Fahrasa (1998), 91; al-Dhahabī, Siyar (1992), 16: 68.

33 Al-Dhahabī (d. 748 H/1348 CE) maintains in Siyar a 'ām al-nubalā' that Jāmi 'al-Tïrmidhī entered al-Andalus only after the death of Ibn Ḥazm (d. 456 H/1064 CE) and in Mìzān al-i 'tidāl he states that the Jāmi' was unknown to Ibn Hazm (innahu majhūl) and that he had never heard about its existence nor its 'ilal. See al-Dhahabī, Mìzān al-i'tidāl (1963), 3: 678; al-Dhahabī, Siyar (1992), 18: 202. Indeed, Ibn 'Abd al-Barr (d. 463 H/1071 CE), who was a teacher and close companion of Ibn Ḥazm, taught the Jāmi' to his disciples and heard it from Abū 'Alī al-Ghassānī alJayyānī (d. 498 H/1105 CE). In addition, as we know that he never left al-Andalus, Jāmi' al-Tirmidhī must have been brought there at least sixty years before the death of Ibn Hazm. This is an indication, partial but pertinent, that Ibn Hazm may have heard about al-Tirmidhī and his Jāmi '; however, if this were the case, it is not clear why he would have failed to ever mention it. See Ibn 'Atiyya, Fahrasa (1983), 70; Robson 1954, 259. In spite of what al-Dhahabī reported, it is recorded in Ibn 'Ațiyya's Fihrist that Yaḥyā b. Muhammad b. Yūsuf Ibn al-Jayyānī (d. 390 H/1000 CE) introduced al-Tirmidhī’s Jāmi ' into al-Andalus, as Robson 1954, 259 already pointed out.

34 See more in Brown 2011.

35 Fierro 2011, 76. 
The Șahịh al-Bukhārī reached Kairouan in the year 357 H/967 CE thanks to Abū al-Ḥasan 'Alī al-Qābisī (d. 403 H/1012 CE), a prominent Qayrawānī jurist and traditionist. ${ }^{36}$ 'Abd Allāh al-Așīlī (d. 392 H/1001 CE), one of al-Qābisī’s students who had accompanied him on his rihla, entered al-Andalus during the final days of al-Hakam al-Mustanșir's rule, in 366 H/976 CE, and brought with him the Sahịh. ${ }^{37}$ As regards the introduction of Muslim's Șahịh into the Maghrib, Cordoban imām and muhaddith Qāsim b. Aṣbagh (d. 340 H/951 CE) is said to have written a compilation of hadìth based on Muslim's work: Kitāb al-Ṣạ̣ị̣ 'alā hay'at Ṣaḥị̣ Muslim. ${ }^{38}$ The aforementioned Yaḥyā b. Muhammad b. Yūsuf Ibn al-Jayyānī (d. $390 \mathrm{H} / 1000 \mathrm{CE})^{39}$ is explicitly mentioned as having introduced this work into alAndalus. ${ }^{40}$

To summarize, although initially in the Maghrib Mālikī jurists paid little attention to the reception of ahädith and 'ilm al-hadith, from the 4th/10th century onwards, after the introduction of most of the so-called six canonical collections, the circulation of hadith increased, as did its study and its development as a genre. From then on, many Maghribi scholars devoted their lives to studying the prophetic tradition in all its aspects. They scrutinized the materials, commented on them, wrote glosses (hāshiyāt), summaries (talākhiss) and abridged versions (mukhtașarāt), and commented on the mutūn and asānìd. Moreover, they looked into its problems (mushkilāt) and terms (alfāz), added epilogues (takmilāt), researched the biographies of the traditionists (taräjim), determined and identified its authorities (rijāl), composed prefaces (iftitāhiyyāt) and conclusions (khatamāt), etc. The high proficiency that Maghribi scholars attained in 'ilm alhadith allowed them to make specific contributions in this field, which we will now examine.

\subsection{The development of hadith commentaries in the Maghrib}

A significant corpus of hadith and legal literature was produced in the Maghribi milieu; as stated by Blecher,

Beginning in the 10th, 11th and 12th centuries, largely but not exclusively among Maliki hadith scholars in southern Spain and North Africa, the hadith collections themselves came

36 Al-Qābisī, al-Risāla (1986), 9 .

37 Ibn al-Faradīi, Ta'rīkh (2008), 1: 335.

38 Al-Dhahabī, Tadhkirat al-huffāz (1971), 2: 49.

39 See footnote 33.

40 Ibn al-Faraḍī, Ta’rīkh (2008), 2: 244; Makkī 1968, 203. 
to be understood as worthy of systematic commentary. These commentaries took the form of live lessons, oral glosses during a recitation of hadith commentary, and multivolume written works for use as reference during devotional study, recitation, legal instruction, and legal practice. ${ }^{41}$

Before this development took place, Maghribi scholars had already written commentaries, starting with al-Mudawwana al-kubrā by Qayrawānī jurist al-Imām Saḥnūn (d. 240 H/854 CE), a work that, to quote Nicole Cottart, is "à l'origine de toute littérature de commentaires". ${ }^{42}$

Based on al-Asadiyya, ${ }^{43}$ Sahnūn developed the legal basis established by Mālik in the Muwatta' through his dialogue with Mālik's direct disciple, the Egyptian jurist Ibn al-Qāsim (d. 191 H/806 CE). Although Sahnūn's own opinions are sparse, he wrote down all that he had heard, and then sifted through the material, classifying and systematizing it. ${ }^{44}$ One of al-Ghāzī b. Qays's disciples, 'Abd al-Malik b. Habīb (d. 238 H/854 CE), composed the first commentary on the Muwatța', entitled Tafsïr gharīb al-Muwatța'. ${ }^{45}$

As for the first commentary on Șahịh al-Bukhārin, it is generally assumed that it was written by al-Khațāābi (d. 388 H/988 CE), with the title A lām al-hadìth fi sharh Șahịh al-Bukhārī. ${ }^{46}$ Around the same time, the Maghribi scholar Abu Ja far Aḥmad b. Nașr al-Dāwūdī al-Tilimsānī (d. 402 H/1011 CE) wrote a commentary known as al-Nașīha fi sharh al-Bukhārī. ${ }^{47} \mathrm{Al}$-Khațțābī, an Easterner - whose work is preserved and can be found in modern editions - died fourteen years earlier than al-Dāwūdī, whose work has since been lost. Al-Khaț̣ābì declares in his commentary's preface that after the insistence of his disciples in Balkh ${ }^{48}$ he decided to dictate his sharh there. ${ }^{49} \mathrm{Al}$-Dāwūdī, on the other hand, wrote his commentary

41 Blecher 2016, 1.

42 Cottart, "Mālikiyya”, $E I^{2}$, 6: 263.

43 The legal work by Asad b. al-Furāt, who composed it in Egypt after discussing 36,000 juristic themes (masā’il fiqhiyya) with Ibn al-Qāsim. See Ziriklī 2002, 298.

44 Puente 1995, 311.

45 Al-Dhahabī, Siyar (1992), 12: 103; Ibn Ḥabīb, Tafsīr (2001), 1: 151-154; Muranyi 1997, 88.

46 Al-Dimashqī 1988, 623. It is possible that al-Khaț̣ābī's commentary could either be in Khizānat al-Qarawiyyin in Fez among the non-catalogued list of manuscripts, or could have been lent out and unfortunately not been returned. See al-Kattānī, Madrasa (n.d.), 2: 569, 580-581.

47 Qāọī 'Iyāọ, Tartīb al-madārik (1983), 7: 103; Ibn Farḥūn, al-Dībāj (1972), 1: 166. Al-Dāwūdī also wrote a commentary on the Muwațta' titled al-Nāmi fi sharh Muwațta' al-Imām Mālik. To my knowledge the work is not preserved, so we do not know exactly what kind of commentary it was.

48 In the north of Afghanistan.

49 Al-Khaț̣āaī, A lām al-ḥadìth (1988), 1: 101. 
in Tlemcen, far in the West. ${ }^{50}$ There is, moreover, no indication that the two ever met. Al-Dāwūdī's commentary was the first commentary on the Șahịh of al-Bukhārī written in the Maghrib; although it has not been preserved, it is described as having been extensive and precise. ${ }^{51}$ As we can gather based on al-Dāwūdì's date of death, his commentary was written at roughly the same time as that of alKhațāābi, which is usually given precedence without taking into account this Western counterpart.

During Ramaḍān of the year 499 H/1106 CE, in the great mosque of al-Mahdiyya, al-Imām al-Māzarī (d. 536 H/1141 CE) dedicated his lessons to the study of Sahịh Muslim. At the end of the month ${ }^{52}$ his disciples gave him their notes of his dictations. He added and removed passages, rearranged it, and named it alMu'lim bi-fawā'id Muslim. ${ }^{53}$ All the commentaries composed before al-Mu'lim were either unfinished works or belonged to the genre of sharh gharīb al-ḥadìth, which focused on explaining difficult, unusual and obscure words. ${ }^{54}$ Therefore,

50 Mawsū'at al-'ulamā' (2013), 2: 10; Nwīhiḍ 1980, 140.

51 Al-'Aynī, 'Umdat al-qāri' (n.d.), 2: 277, 8: 40, 16: 202; Ibn Ḥajar al-'Asqalānī, Fatḥ al-bārī (1960), 3: 99; al-Qasțalānī, Irshād al-sārī (1905), 1: 42.

52 Ramaḍān 499 fell in June 1106, which implies more hours of daylight, and thus longer sessions or lectures. This strengthens the hypothesis of al-Nayfar, who asserted that the whole work was dictated during the month of Ramaḍān, despite descriptions of how careful and slow alMāzarī’s dictations were. See al-Māzarī, al-Mu 'lim (1988), 1: 193.

53 In the majority of biographical books (kutub al-taräjim) the work is entitled al-Mu'lim bifawā'id Muslim, as Ibn Khalqān, Ibn Khaldūn, Ibn 'Imād al-Ḥanbalī, Ibn 'Ațiyya and others maintained. However, Qāḍi 'Iyāḍ, for instance, in the biographical work dedicated to his teachers, al-Ghunya, specifies that he received by licence from al-Māzarī his work al-Mu lim fì sharh Muslim. See Qāḍī 'Iyāọ, Tartīb al-madārik (1982), 65; al-Māzarī, al-Mu 'iim (1988), 1: 190-192.

54 While al-Mufhim fi sharh gharīb Muslim composed by Abū al-Ḥasan 'Abd al-Ghāfir b. Ismā'îl al-Fārisī (d. 529 H/1135 CE) paid attention to difficult and unclear terms (gharīb al-hadìth) (see Ibn Khallikān, Wafayāt al-a yānn [1978], 3: 225), Ibn al-Ḥājj's (d. 529 H/1135 CE) al-İjāz wa-l-bayān li-sharh khuțbat kitāb Muslim ma'a kitāb al-İmān had been limited to the commentary of the first chapter of the Șahinh, and remained unfinished at the time of the author's death (see Ibn Khayr, Fahrasa [1998], 165). 'Abd Allāh b. 'Īsā al-Shaybānī al-Andalusī (d. 530 H/1136 CE) likewise passed away before finishing his commentary, entitled Sharḥ Șaḥị Muslim (see Ibn Bashkuwāl, al-Sila [2010], 1: 385). Another commentary appeared in the same period as al-Mu 'lim, namely alIrshād by Ibn Barrajān (d. 536 H/1141 CE). However, he limited his commentary only to the traditions containing Qur'ānic verses (see al-Kattānī al-Fāsī, Nizām al-ḥukūma [n.d.], 2: 141). Finally, Abū al-Qāsim Ismā īl b. Muhammad al-Ișbahānī (d. 530 H/1136 CE) took the helm after the death of his son, who had passed away while working on his commentary to the two Șahịhayn (see Ḥājjī Khalīfa, Kashf al-zunūn [1941], 2: 558). 
al-Māzarī's is considered to be the first comprehensive commentary on Șahīh Muslim and an important pillar upon which most later commentaries were built. ${ }^{55}$

The Sevillian jurist Abū Bakr b. al- 'Arabī al-Ishbīlī's (d. 543 H/1148 CE) commentary, entitled 'Ârị̣at al-aḥwadhī fì sharh al-Tïmidhī, was the first Maghribi commentary on al-Tirmidhī's Jāmi '. ${ }^{56}$ Ibn 'Asākir (d. 571 H/1176 CE), in his account of the life of Ibn al-'Arabī, asserts that after returning to al-Andalus after his long rihla in $495 \mathrm{H} / 1100 \mathrm{CE}$, he devoted a sharh to Jāmi ' Abi ' $\bar{I} s \bar{a}$ al-Tirmidhì. ${ }^{57}$ In the chapter “Abwāb al-qirā'āt”, Ibn al-'Arabī states that he dictated it in $533 \mathrm{H} /$ 1138 CE (amlaynāhu sanat thalāth wa-thalāthīn bi-jamī' i wujūhihā). Likewise, Abū Yūsuf Ya'qūb b. 'Abd al-Salām al-Zuhrī, one of Ibn al-'Arabī's disciples, says that he heard him dictate 'Ārị̣at al-ahwadhì in $540 \mathrm{H} / 1145 \mathrm{CE}$, ${ }^{58}$ just three years before his death and after having written his works Ahkām al-Qur' $\bar{a} n^{59}$ and al-Qabas. ${ }^{60}$ Thus, he wrote this commentary during a period of intellectual maturity and after having abandoned his position as judge, at a time when he was able to devote all his energies to writing (tașnîf), dictation (imlā') and teaching (tadrīs). ${ }^{61}$

In the Islamic West, the genre of hadith commentaries was nurtured by the increase and diversification of the shurūh produced there. Many of these commentaries, e.g. al-Mu 'lim and 'Árị̣at al-aḥwadhì, were influential sources of inspiration for later works. ${ }^{62}$ We might ask, then, in what ways this Maghribi influence shows up in works by Mashriqi scholars.

55 Sezgin 1967, 1: 136, 137.

56 Brockelmann and Sezgin mention the presence of a manuscript of a sharh in the Mahmūdiyya Library in Medina (only the last part according to Spies 1936) attributed to alḤusayn b. Mas' 'ūd al-Baghawī (d. 510 H/1117 CE). See Brockelmann 1977, 3: 190; Sezgin 1967, 1: 155. Nevertheless, none of the biographical dictionaries mentions this, and in the introduction to his commentary, Jalāl al-Dīn al-Suyūṭi denies the existence of other commentaries before 'Ārị̣at al-aḥwadhī. See al-Suyūțī, Qūt al-mughtadhī (2013), 1: 18.

57 Ibn 'Asākir, Ta'rīkh (1997), 54: 24.

58 A'rāb 1987, 111.

59 He finished it in 530 H/1135-6 CE. See Ibn al-'Arabī, Aḥkām al-Qur'ān (2003), 7: 151.

60 He dictated it in 532 H/1137-8 CE. See Ibn al-'Arabī, al-Qabas (1992), 66.

61 Ibn Bashkuwāl, al-Ṣila (2010), 2: 228.

62 Both the title and content influenced later commentaries: Ikmāl al-Mu lim fi sharh Șaḥịh Muslim, Ikmāl li-l-Qāộ̄ 'Iyāẹ, Ikmāl al-Ikmāl, Ikmāl Ikmāl al-Mu 'lim, Tuhfat al-aḥwadhī sharḥ Jāmi' al-Tirmidhī. 


\section{The Șaḥị̣ Muslim as a case study}

\subsection{Maghribi commentaries on Șaḥị̣ Muslim}

Once it was introduced into the Maghrib, Muslim's Șahịh drew the attention of the scholars who encountered it, as reflected in the diversity and the number of works they composed on it. The Eastern authors Ibn al-Ṣalāh (d. 643 H/1245 CE) $)^{63}$ and al-Nawawī (d. $676 \mathrm{H} / 1277 \mathrm{CE}){ }^{64}$ as well as the Maghribi al-Tujībì (d. $730 \mathrm{H} /$ $1329 \mathrm{CE})^{65}$ and other scholars claimed that Șaḥịh Muslim was preferred over Șaḥịh al-Bukhārn in the western Islamic lands. ${ }^{66}$ Ibn Khaldūn (d. 808 H/1406 CE) confirms this:

The Șahịh of Muslim has been given much attention by Maghribi scholars. They applied themselves to it and agreed that it was superior to the work of al-Bukhārī. Ibn aș-Ṣalāh said: "It is considered superior [by Maghribis and other scholars] to the work of al-Bukhārī, because it is free from admixtures of material that is not sound and that al-Bukhārī wrote down disregarding his own conditions [of soundness], mostly in connection with the chapter headings". ${ }^{67}$

From what I have found in the biographical books (kutub al-tarājim), together with kutub al-barāmij and al-fahāris, that I have consulted, ${ }^{68}$ I have provisionally concluded that commentaries (shurūh) comprised the lion's share as compared to the other genres within 'ilm al-hadith. As mentioned above, the Mu lim of alMāzarī is considered the first and oldest complete commentary on Muslim's compilation. In this table, I have placed the Maghribi commentaries in ascending order according to the scholars' date of death.

63 Ibn al-Ṣalāḥ, Șiyāna (1984), 70.

64 Al-Nawawī, al-Minhāj (2000), 21.

65 Al-Tujībī, Barnāmaj (1981), 93.

66 For more details about the preference for Șaḥị̣ Muslim over Șaḥịh al-Bukhārī, see Trad (in press), 5-6.

67 Ibn Khaldūn, al-Muqaddima (1958), 2: 459.

68 Kutub al-barāmij wa-l-fahāris wa-l-ma'ājim wa-l-athbāt are bibliographical dictionaries that focus on the transmission of works in different disciplines. For a detailed review on this topic, see 'Amad 1993, 11-15. 
Tab. 1: Maghribi commentaries on Șaḥị̣ Muslim

\begin{tabular}{|c|c|}
\hline Scholars & Works \\
\hline al-Māzarī (d. 536 H/1141 CE) & al-Mu'lim bi-fawā’id Muslim \\
\hline Qāḍī 'lyāọ (d. 544 H/1149 CE) & Ikmāl al-Mưlim fĩ sharḥ Șaḥị̣ Muslim \\
\hline Ibn Mawjuwāl al-Balansī (d. 566 H/1170 CE) & Sharh fị Șaḥị̣ Muslim \\
\hline Ibn Qurqūl (d. 569 H/1173 CE) & Mațāli' al-anwār 'alā Șị̣āḥ al-āthār \\
\hline Ạ̣mad b. Yaḥyā al-Ḍabbī (d. 599 H/1202 CE) & Mațāi' al-anwār li-Ṣị̣āḥ al-āthār \\
\hline $\begin{array}{l}\text { Ibn Abī Jamra, Muḥammad b. Aḥmad } \\
\text { (d. } 599 \text { H/1202 CE) }\end{array}$ & Sharḥ Șaḥị̣ Muslim \\
\hline $\begin{array}{l}\text { Abū Ja'far Aḥmad al-Dhahabī al-Balansī } \\
\text { (d. } 601 \mathrm{H} / 1204 \mathrm{CE} \text { ) }\end{array}$ & Sharḥ Șaḥị̣ Muslim \\
\hline $\begin{array}{l}\text { 'Alī b. Aḥmad al-Ghassānī al-Wādī Āshī } \\
\text { (d. } 609 \text { H/1212 CE) }\end{array}$ & Iqtibās al-sirāj fi sharḥ Muslim Ibn al-Ḥajjāj \\
\hline Ibn al-Mawwāq (d. 642 H/1244 CE) & Sharḥ Muqqadimat Șaḥịh Muslim \\
\hline $\begin{array}{l}\text { Abū 'Abd Allāh Yaḥyā al-Anșārī (d. } 646 \text { H/ } \\
1248 \text { CE) }\end{array}$ & $\begin{array}{l}\text { al-Mufșih al-mufhim wa-l-muwaḍ̣aḥ al-mul- } \\
\text { him li-ma'ānì Șah̄ịh Muslim }\end{array}$ \\
\hline Abū al-'Abbās al-Qurțubī (d. 656 H/1258 CE) & al-Mufhim li-mā ashkala min talkhīṣ Kitāb Muslim \\
\hline Ibn Abī al-Aḥwaș (d. 679 H/1280 CE) & al-Mu'rib al-mufhim fĩ sharh Muslim \\
\hline $\begin{array}{l}\text { Abū 'Abd Allāh al-Laythī al-Andalusī } \\
\text { (d. } 707 \text { H/1307 CE) }\end{array}$ & Ikmāl li-l-Qāậ̄ lyāọ \\
\hline $\begin{array}{l}\text { Muḥammad b. Juzayy al-Kalbī al-Gharnațī } \\
\text { (d. } 741 \text { H/1340 CE) }\end{array}$ & Wasīlat al-muslim fĩ tahdhīb Șaḥị̣ Muslim \\
\hline $\begin{array}{l}\text { Abū al-Faraj 'T̄sā b. Mas'ūd al-Zawāwī } \\
\text { (d. } 744 \text { H/1343 CE) }\end{array}$ & Sharḥ Muslim \\
\hline $\begin{array}{l}\text { al-Sharīf al-Sallāwī al-Idrīsī (d. } 780 \text { H/ } \\
1378 \text { CE) }\end{array}$ & Ikmāl al-Ikmāl \\
\hline $\begin{array}{l}\text { Abū 'Abd Allāh al-Ubbī al-Tūnisī (d. } 827 \text { H/ } \\
1423 \text { CE) }\end{array}$ & Ikmāl Ikmāl al-Mu'lim \\
\hline Ibn al-Shāṭ (d. 890 H/1485 CE) & Tálīq 'alā Șaḥị̣ Muslim \\
\hline $\begin{array}{l}\text { Abū 'Abd Allāh al-Sanūsī al-Ḥusaynī } \\
\text { (d. } 895 \text { H/1489 CE) }\end{array}$ & Mukammal lkmāl al-Ikmāl \\
\hline $\begin{array}{l}\text { Muḥammad b. Muḥammad al-Marrākushī } \\
\text { (d. } 1348 \text { H/1929 CE) }\end{array}$ & Bughyat kull muslim min Șaḥị̣ Muslim \\
\hline
\end{tabular}

The analysis of the Maghribi commentaries that follows below - in this case, two have been selected - will allow us to gain a better understanding of the importance and reception of these works in the East, and will shed some light on the Maghrib's impact on the Mashriq. 


\subsubsection{Qāḍī 'Iyāọ’'s commentary}

As the title Ikmāl al-Mu 'im fi sharh Muslim indicates (ikmāl meaning "completion”), the commentary of Qāọī 'Iyāọ sought to rearrange and further develop a pre-existing work elaborated by al-Māzarī, al-Mu'lim bi-fawā'id Muslim. ${ }^{69}$ In addition, Qāḍī 'Iyāḍ’'s Ikmāl al-Mu 'im was based on the book Taqyīd al-muhmal by Abū 'Alī al-Ghassānī al-Jayyānī (d. 498 H/1105 CE). ${ }^{70}$ In the introduction, 'Iyāḍ pays tribute to the high status of both works and to their important contribution to the genre. However, he also asserts that the authors overlooked certain problematic traditions, unclear terms and other other sources of confusion. With this in mind, and with the continued insistence of his disciples, Qāḍi 'Iyāḍ decided to take the helm from his teachers and write a complete, comprehensive and detailed commentary. ${ }^{71} \mathrm{Ikma}$ a al-Mu 'lim was the first link in the chain of consecutive commentaries based on al-Mu 'lim, i.e. Ikmāl li-l-Qāḍ̂̀ 'Iyāẹ by Abū 'Abd Allāh alLaythī al-Andalusī (d. 707 H/1307 CE), Ikmāl al-Ikmāl by al-Sharīf al-Sallāwī alIdrīsī (d. 780 H/1378 CE), Ikmāl Ikmāl al-Mu lim by Abū 'Abd Allāh al-Ubbī alTūnisī (d. 827 H/1424 CE) and Mukammal Ikmāl al-Ikmāl by Abū 'Abd Allāh alSanūsī al-Ḥusaynī (d. 895 H/1490 CE).

\subsubsection{Al-Qurțubỉs (578-656 H/1182-1258 CE) commentary}

To assess the real value of Qāọī 'Iyāḍ's contribution and his continuators, previous and later commentaries on Șahị Muslim need to be taken into account, together with the intellectual atmosphere in which they arose. Abū al-'Abbās alQurtubì lived in the period where "the study of ahādith became widespread". ${ }^{72}$ His commentary to Muslim's work, entitled al-Mufhim fì sharḥ kitāb Șaḥị̣ Muslim, is preserved in many manuscripts, of which there are a number of modern editions. Although a sizeable number of hadith commentaries had already been circulating in both the Maghrib and the Mashriq, the Mufhim managed to reach a sizeable audience because of its crucial role as an interface between, on the one

69 Al-Māzarī was Qāḍī 'Iyāḍ̂s teacher by correspondence, as Qāọī 'Iyāḍ̂s riḥla was only to alAndalus. Al-Māzarī gave him the license to transmit his work al-Mu lim (ajāza lahu bihi).

70 Taqyīd al-muhmal wa-tamyiz al-mushkil fi rijāl al-Ṣahịhayn is a compilation of the authorities in the Șahihhayn. It accurately verifies their names (asmä), agnomens (kunā) and lineages (an$s \bar{a} b$ ); highlights and corrects mistakes; and presents these authorities' origins and tribal affiliations. See al-Ghassānī al-Jayyānī, Taqyīd al-muhmal (2000), 93; Serrano Ruano 2013, 299.

71 Qāḍi 'Iyāọ,, Ikmāl al-Mu'lim (1998), 1: 71-72.

72 Fierro 2011, 77. On al-Qurțubī see Kaddouri 2005, 160-207. 
hand, al-Māzarī and Qāḍī 'Iyāọ, and, on the other, al-Ubbī and al-Sanūsī. ${ }^{73}$ In addition, this commentary is distinguished by offering a readily comprehensible synthesis, coupled with an inimitable simplicity (al-sahil al-mumtana ), ${ }^{74}$ as indicated in the title, where mufhim means "that which makes intelligible".

As for the date and place where al-Mufhim was written, they are not mentioned in the book. However, al-Qurțubī does make reference to his own previous works, and explicitly discusses his trip to the East, after which he settled in Alexandria. ${ }^{75}$ Thus, this commentary must have been composed for the most part in Egypt, and more specifically in Alexandria, between $619 \mathrm{H} / 1222 \mathrm{CE}$ and $656 \mathrm{H} /$ 1258 CE. $^{76}$

\subsection{The impact of Ikmāl al-Mu'lim and al-Mufhim on later Eastern commentaries}

What sort of influence did Qāọ̄i 'Iyāọ and Abū al-'Abbās al-Qurṭubī's commentaries have on the Mashriq? This can be ascertained on two levels: form and content.

As for form, the chapter division (tabwīb) of Muslim's Șahịh is attributed to Yahyā b. Sharaf al-Nawawī (d. 676 H/1277 CE). ${ }^{77}$ Muslim, in fact, did not divide his book into chapters (kutub) and subchapters $(a b w a \bar{b}),{ }^{78}$ but rather arranged the traditions following a logic-based and juristic order (tartīb fiqhī) ${ }^{79}$ possibly in order to save space and avoid redundancy. While the oldest copies of the Sahin h - e.g. the copy of Abū Ishāa al-Ṣirīfaynī (d. 641 H/1242 CE) - do not contain the $a b w \bar{a} b,{ }^{80}$ the later ones are arranged differently, and these differences vary from place to place and according to the schools of law. ${ }^{81}$ Al-Suyūṭi (d. 911 H/1505 CE)

73 Al-Qurțubī, al-Mufhim (1996), 1: 17.

74 Al-Qurțubī, al-Mufhim (1996), 1: 17.

75 Al-Qurțubī, al-Mufhim (1996), 6: 25-26.

76 For the dates of al-Qurțubī's return from his pilgrimage to Alexandria and his death, see Kaddouri 2005, 192.

77 Al-Mundhirī, Mukhtașar (1987), 9.

78 In fact, the kutub form part of the process of tabwīb, since the kitāb is actually a large $b \bar{a} b$ with internal ramifications or subchapters.

79 Āl H.umayyid 1999, 40.

80 Salmān 1994, 175.

81 There is, of course, still some ambiguity concerning Qāḍi 'Iyāḍ’s assertion that some copies of Muslim were divided into chapters similarly to al-Bukhārī (wa-qad waqa'a li-Muslim fì ba'd tarājimihi min ba'ḍ al-riwāyāt mithla tarjamat al-Bukhārī 'alā hādhā al-ḥadìth, wa-nașṣuhu: bāb 
agrees that Muslim did not divide his book in this way, and that the division was undertaken by those who came after him. ${ }^{82}$ Accordingly, al-Māzarī arranged his commentary into forty-one chapters, two subchapters entitled "bāb al-qasāma" and "bāb al-shi'r", and one independent part called "al-luqața". Later on, in Ikmāl al-Mu'lim, Qāọī 'Iyāọ eliminated eight chapters ${ }^{83}$ from the previous commentary, added twenty new ones, ${ }^{84}$ and divided each chapter into subchapters.

Al-Nawawī essentially followed Qāọī 'Iyāḍ’s divisions, excluding five $k u t u b^{85}$ and reintegrating "kitāb qatl al-ḥayyāt wa-ghayrihā", from al-Māzarī’s commentary. The example in Table 2 shows the development from al-Māzarī's arrangement to the work carried out by Qāḍī 'Iyāọ and its reception by al-Nawawì.

al-tațayyub ba'd al-ghusl min al-janāba). See Qāḍī 'Iyāḍ, Ikmāl al-Mu'lim (1998), 2: 160. In addition, the eminent traditionist of Córdoba and teacher of Qāḍi 'Iyāḍ, Abū 'Alī al-Ghassānī alJayyānī, mentions in his Taqyīd al-muhmal one of the abwāb of Muslim: wa-akhraja Muslim fi bāb tasmiyat al-Mawlūd (al-Ghassānī al-Jayyānī, Taqyīd al-muhmal [2000], 905). The fact that the teacher and his disciple referred to the $a b w a \bar{a} b$ of Muslim is a strong indication that they were both using the same copy of the Șahih h, which employed this structure. In the case of the Maghrib, the most well known copy circulating there was that of Abū Muhammad Ahmad b. 'Alì b. alHasan b. al-Mughīra b. 'Abd al-Raḥmān al-Qalānisī (date of death unknown). On the other hand, the version of Ibn Sufyān (d. 308 H/920 CE) was at the same time gaining ground and had been used by the majority of scholars. Therefore, regardless of whether Muslim arranged his book into $k u t u b$ and $a b w \bar{a} b$ or not, the role of the Maghrib is crucial here, because it was there that this concept of $t a b w i ̄ b$ first appeared, whether in al-Qalānisī's version or in a Maghribi hadith commentary. For further information about al-Qalānisī’s copy see Trad (in press).

82 See Appendix.

83 "Kitāb al-taflīs", "kitāb al-shuf'a”, "kitāb al-sariqa”, "kitāb al-qaḍā' wa-l-shahādāt”, "kitāb al-aț ima”, "kitāb al-țibb”, "kitāb al-țā ūn”, and "kitāb al-manāqib”.

84 "Kitāb al-ḥayḍ”, "kitāb al-masājid wa-mawāḍi al-ṣalāt”, "kitāb ṣalāt al-musāfirīn”, "kitāb al-jum 'a”, "kitāb șalāt al-'īdayn”, "kitāb șalāt al-istisqā’”, "kitāb al-kusūf”, "kitāb al-i'tikāf”, "kitāb al-li'ān”, "kitāb al-hibāt”, "kitāb al-wașiyya”, "kitāb al-ḥudūd”, "kitāb al-aqụiya”, "kitāb al-salām”, "kitāb al-alfāẓ min al-adab”, "kitāb al-faḍā'il”, "kitāb faḍāil al-ṣahāāba”, "kitāb al'ilm”, "kitāb al-tawba”, and "kitāb al-janna wa-ṣifat na īmihā wa-ahlihā”.

85 "Kitāb al-ṣiyām”, “kitāb al-rị̣ā’”, "kitāb al-'itq”, "kitāb al-musāqāt”, and "kitāb al-nadhr”. 
Tab. 2: The arrangement of “kitāb al-qadar” in al-Māzarī, Qāội 'lyāọ and al-Nawawī’s commentaries on the Șạịh of Muslim

\section{“Kitāb al-qadar” in al-Mu'lim “Kitāb al-qadar” in Ikmāl al- “Kitāb al-qadar” in al-Minhāj by al-Māzarī Mu'lim by Qāọī 'Iyāọ by al-Nawawī}

Taḥrīr al-Māzarī li-qawlihi: mā min nafs manfūsa illā waqad kataba Allāh makānahā fī al-janna wa-l-nār...

Ḥadīth ị̣tijāj Ādam wa-Mūsā 'alayhimā al-salām wa-izālat mā yarid fī hādhā al-maqām

Ḥadīth "latarkabanna

sunana man qablakum"

Qawluhu: inna qulūba banī

Ādam bayn iṣba'ayn min așābi Allāh

Ḥadīth “mā min mawlūd illā yūladu 'alā al-fițra faabawāhu yuhawwidānihi wayunașșirānihi wa-yumajjisānihi”" Ikhtilāf al-nās fī al-mutashābah
Bāb kayfiyyat khalq al-ādamī fī baṭn ummihi wa-kitābat rizqihi wa-ajalihi wa-'amalihi washaqāwatihi wa-sa'ādatihi

Bāb ḥijāj Ādam wa-Mūsā 'alayhimā al-salām

Bāb tașrīf Allāh ta'ālā al-qulūb kayfa shā'a

Bāb kullu shay' bi-qadar

Bāb quddira 'alā Ibn Ādam ḥaḍḍhu min al-zinā wa-ghayruhu

Bāb ma'nā kull mawlūd yūladu 'alā al-fiṭra wa-ḥukm mawt aṭfāl al-kuffār wa-aṭfāl al-muslimīn
Bāb kayfiyyat khalq al-ādamī fī bațn ummihi wa-kitābat rizqihi wa-ajalihi wa-'amalihi washaqāwatihi wa-sa'ādatihi Bāb ḥijāj Âdam wa-Mūsā 'alayhimā al-salām

Bāb tașrīf Allāh ta'ālā al-qulūb kayfa shā'a

Bāb kullu shay' bi-qadar Bāb quddira 'alā Ibn Ādam ḥaḍḍuhu min al-zinā wa-ghayruhu

Bāb ma'nā kull mawlūd yūladu 'alā al-fițra wa-ḥukm mawt aṭfāl al-kuffār wa-aṭfāl al-muslimīn
Bāb bayān anna al-ājāl wa-larzāq wa-ghayruhā lā tazīd walā tanquṣu 'ammā sabaqa bihi al-qadar

Bāb fĩ al-amr bi-l-quwwa watark al-`ajz wa-l-isti'āna bi-Llāh wa-tafwīḍ al-maqādīr li-Llāh
Bāb bayān anna al-ājāl wa-larzāq wa-ghayruhā lā tazīd wa-lā tanquṣu 'ammā sabaqa bihi al-qadar

Bāb fī al-amr bi-l-quwwa watark al-‘ajz wa-l-isti‘āna bi-Llāh wa-tafwīc̣ al-maqādīr li-Llāh

Given this example, the assertion that it was al-Nawawī who arranged the Șahịh should be called into question, ${ }^{86}$ because this was $a$ fortiori a task that had already

86 Admittedly, it could still have been argued until 1988 or 1998, the dates when al-Mu 'lim and then Ikmāl al-Mu 'lim were published, thereby making it possible to refute this attribution. 
been carried out by previous Maghribi traditionists, the results of which were afterwards adopted in the Mashriq.

Turning now to the level of content, here the impact of Maghribi commentaries on Mashriqi works is immediately perceptible. The analysis I have carried out of al-Nawawi's commentary has shown that the roots of his sharh are to be found in the Ikmāl al-Mu 'lim. This can be clearly ascertained in al-Nawawì's own words in the "kitāb al-īmān", where he discusses the hadìth "man māta wa-huwa ya lamu anna lā ilāha illā Allāh dakhala al-janna”. Al-Nawawī asserts that Qāḍi 'Iyāḍ's painstaking explanation of this hadith was highly valuable (jama'a fìhi nafā'is) and that he will be quoting from and abridging Qāḍī 'Iyāọ's words ( $f a-$ anā anqulu kalāmahu mukhtașaran), followed by his own additions. ${ }^{87}$

Maghribi commentaries' impact on the East was not limited to works addressing Muslim's Șahīḥ; it also extended to the shurūḥ of Șaḥiḥ al-Bukhārī. Abū al-'Abbās al-Qurțubī's al-Mufhim inspired many scholars dealing with alBukhārī's work. This was especially true with Ibn Ḥajar al-'Asqalānī (d. 852 H/ 1449 CE) in his Fath al-bārī, Badr al-Dīn al- 'Aynī (d. 855 H/1451 CE) in 'Umdat alqāri', and Shihāb al-Dīn al-Qasțalānī (d. 923 H/1517 CE) in Irshād al-sārī. AlMufhim was of great help in explaining the meanings of ambiguous terms in the titles of the chapters and subchapters. Thus, in Fath al-bārī, in "kitāb al-ḥajj", "bāb faḍl al-ḥajj al-mabrūr”, Ibn Hajar quotes al-Qurțubī’s commentary. ${ }^{88}$ It was also a reference concerning the explanation of the ambiguous and less readily understood terms (sharh gharīb al-hadith), ${ }^{89}$ the verification and rectification of the main text of the report (dabt al-matn), ${ }^{90}$ the declension of some terms ( $i^{\prime} r \bar{b} b$ al-alfāz), ${ }^{91}$ the assemblage of traditions (al-jam' bayn al-ahāaith), ${ }^{92}$ etc. The Mufhim also served as a source for correcting issues related to the Māliki school of law and certain Mālikī rituals, such as raising the hands during prayer. ${ }^{93}$

Within this context, I will provide an example showing how an idea that appeared first in the Maghrib started to circulate outside this region and was later introduced implicitly in the Mashriqi commentaries. ${ }^{94}$ In "kitāb al-ḥayḍ" and "kitāb al-qadar”, in Ikmāl al-Mu lim, Qāḍī 'Iyāḍ, when dealing with the morphogenesis of the embryo, maintains that it is formed thanks to the "water" of the

87 Al-Nawawì, al-Minhāj (2000), 105.

88 Ibn Ḥajar al-'Asqalānī, Fatḥ al-bārī (1960), 3: 382.

89 Al-'Aynī, 'Umdat al-qāri' (n.d.), 6: 269.

90 Ibn Hajar al-'Asqalānī, Fatḥ al-bārī (1960), 4: 316.

91 Ibn Hajar al-'Asqalānī, Fatḥ al-bārī (1960), 5: 366.

92 Ibn Ḥajar al-'Asqalānī, Fatḥ al-bārī (1960), 4: 134.

93 Al-Qasțalānī, Irshād al-sārī (1905), 2: 73.

94 I wish to express my gratitude to Prof. Dr. Thomas Eich bringing this example to my attention. 
woman and also the "water" of the man. In order to clarify his opinion, he compares male sperm to rennet and its ability to curdle milk..$^{95}$ The commentary is as follows:

And in it, there is an indication that the child is made of both waters, and this is an answer to those who thought that it is only of the water of the woman, and that the water of the man only has the function of curdling, as with rennet and milk. ${ }^{96}$

Later, Qāọī 'Iyāọ states:

It contains a rejection to the anatomists (ahl al-tashrihh), doctors (wa-[ahl] al-tibb) and philosophers/naturalists (wa-l-țabä' $i$ iyyin) and those who believe in what they say, that is, that the child comes instead from the menstrual blood, and that the semen has nothing to do with its creation, but merely coagulates it ('aqdihi), as with rennet and milk, which the book of God and the authentic ahādith contradict. ${ }^{97}$

One century later, the same comparison appears in the commentary of Abū al'Abbās al-Qurțubī, in "kitāb al-țahāra”:

And these ahädith indicate (...) that the child is made of the water of man and woman, unlike those who thought that the child was made of the woman's water and that the water of the man was the cause of the fermentation like rennet for the milk. And God knows best. ${ }^{98}$

Ibn Ḥajar al-'Asqalānī reproduces the exact same idea with minor differences in word choice:

Many of the anatomists (ahl al-tashrihh) claim that the sperm (manī) of the man has no influence on the child (walad), leaving no trace but his coagulation ('aqd). It arises from the menstrual blood. The ahādith of the chapter nullify this, and what was first mentioned corresponds more closely with the hadith. And God knows best. ${ }^{99}$

95 Qãdị 'Iyāḍ was not the first to make this comparison; it has its roots in the Hellenistic period, descending from Aristotle, Galen and Hippocrates. It also appears in the Hebrew Bible: "Did you not pour me out like milk and curdle me like cheese” (Job 10.10). Qāḍi 'Iyāọ was, however, the first commentator to incorporate this idea into a hadìth commentary. Knowing that Qāḍi 'Iyāḍ travelled many times to al-Andalus, a question that could be raised is whether he heard this information from one of the eminent Andalusi Jewish scholars. For further information about the history of embryology, see Needham 1959.

96 Qāọī 'Iyāḍ, Ikmāl al-Mu lim (1998), 2: 151.

97 Qãạī 'Iyāḍ, Ikmāl al-Mu 'lim (1998), 8: 125.

98 Al-Qurțubī, al-Mufhim (1996), 1: 572.

99 Ibn Ḥajar al-'Asqalānī, Fatḥ al-bārī (1960), 11: 480. 
It resurfaces in Sharh al-arba'īn al-nawawiyya by 'Abd al-Ra' ūf al-Manāwī (d. $1031 \mathrm{H} / 1621 \mathrm{CE})$ under the following form:

And many of the anatomists (ahl al-tashrih) claim that the sperm (manī') of the man has no influence on the child except in his coagulation ('aqd), and that instead it arises from the menstrual blood. And the ahāaith of the chapter nullify this. ${ }^{100}$

There are two key facts at play here. First, we know that after receiving a sound, well-rounded education, al-Qurțubì set out on his riḥla from al-Andalus to the East and that he settled in Egypt, ${ }^{101}$ where he lived until his death in $656 \mathrm{H} /$ 1258 CE. Second, Ibn Ḥajar al-'Asqalānī and al-Manāwī were themselves from Egypt. Therefore, I suggest the following interpretation: al-Qurțubì constituted the link between the Maghrib and the Mashriq, transmitting the knowledge he acquired in Córdoba and al-Mahdiyya to his disciples during his lessons (halaqāt tadris).$^{102}$ If this is the case, we can see how the rihla could in some instances be bidirectional, helping the travelling scholar to widen his knowledge, while at the same time spreading knowledge stemming from his own intellectual and regional/local background.

\section{Conclusion}

In this article I have summarized in diachronic order the chief stages in the introduction of the hadith collections to the Maghrib, and have then discussed how this region shaped the genre of hadith commentary by concentrating on Muslim's Șahị and its commentaries, due to its fame and superiority in the Islamic west. It was here that commentary writing reached its apogee, providing solid foundations on which later works from across the Islamic world would build. Nevertheless, Mashriqi scholars mainly focused on Qāḍi 'Iyāḍ, claiming that "if it were not for [Qāḍi] 'Iyāḍ, the Maghrib would not have been known" (law lā 'Iyāẹ, la-mā 'urifa al-Maghrib), ${ }^{103}$ thereby overshadowing other eminent Maghribi scholars like al-Ghāzī b. Qays, Baqī b. Makhlad, Qāsim b. Aṣbagh, Abū Ja'far b. Nașr al-Dāwūdī, Abū 'Alī al-Ghassānī al-Jayyānī, Abū 'Alī al-Șadafî (d. 514 H/ 1126 CE), al-Māzarī, Abū al-Ḥasan al-Qābisī, and Abū al-Ghayth al-Qashshāsh (d.

100 Berlin, National Library MS 461-1500, fol. 66r.

101 In Alexandria.

102 Ibn Farhūu, al-Dībāj (1972), 1: 131.

103 Ibn Tāwīt 1982, 59. 
$1014 \mathrm{H} / 1622 \mathrm{CE}$ ), whose library boasted more than one thousand copies of the Șahīḥ of al-Bukhārī.

\section{Appendix}

\section{Al-Suyūṭī, Qūt al-mughtadhī (2013), 1: 33}

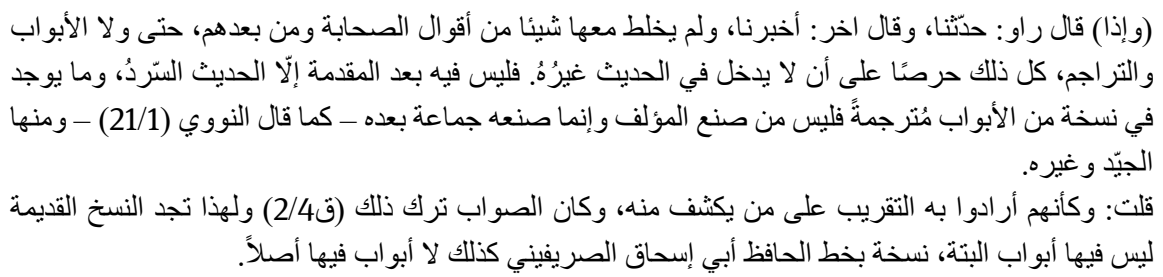

\section{Bibliography}

\section{Primary sources}

Al-'Aynī, Badr al-Dīn Maḥmūd b. Aḥmad (n.d.), 'Umdat al-qāri', ed. n.n., 25 vols, Beirut: Dār alFikr.

Al-Dhahabī, Shams al-Dīn (1963), Mīzān al-ítidāl fĩ naqd al-rijāl, ed. by 'Alī Muhammad al-Bajāwī, 4 vols., Beirut: Dār al-Ma'rifa.

Al-Dhahabī, Shams al-Dīn (1992), Siyar a'lām al-nubalā', ed. by Shu'ayb al-Arna'ūṭ and Ḥusayn al-Asad, 31 vols., Beirut: Mu'assasat al-Risāla.

Al-Dhahabī, Shams al-Dīn (1971), Tadhkirat al-ḥuffāz, ed. by Zakariyyā' 'Umayrāt, 3 vols., Beirut: Dār al-Kutub al-'Ilmiyya.

Al-Ghassānī al-Jayyānī, Abū 'Alī al-Ḥusayn (2000), Taqyīd al-muhmal wa-tamyīz al-mushkil, ed. by 'Alī b. Muhammad al-'Umrān and Muḥammad Shams, Mecca: Dār 'Ālim al-Fawā'id.

Ḥajjī Khalīfa, Muṣtafā b. 'Abd Allāh (1941), Kashfal-ẓunūn 'an asāmī al-kutub wa-l-funūn, ed. by Muḥammad Sharaf al-Dīn Baltaqāyā and Rif'at Balīka al-Kulaysī, 2 vols, Beirut: Dār lḥyā' al-Turāth al-'Arabī.

Al-Ḥimyarī, Muḥammad (1975), al-Raw ạ al-miț̣ār fĩ khabar al-aqțār, Beirut: Librairie du Liban. Al-Ḥumaydī, Muḥammad b. Futūḥ b. 'Abd Allāh (2008), Jadhwat al-muqtabis, ed. by Bashshār 'Awwād and Muhammad 'Awwād, Tunis: Dār al-Gharb al-Islāmī.

Ibn al-Abbār, Abū 'Abd Allāh Muḥammad (1989), al-Mujam, Cairo: al-Maktaba al-Andalusiyya. Ibn al-Abbār, Abū 'Abd Allāh Muḥammad (1995), Takmilat al-Ṣila, ed. by 'Abd al-Salām al-Harrās, 4 vols., Beirut: Dār al-Fikr.

Ibn 'Abd al-Ḥakam, 'Abd Allāh (1964), Futūh Ifrīqiya wa-l-Andalus, ed. by Anīs al-Ṭabbā', Beirut: Dār al-Kitāb al-Lubnānī. 
Ibn 'Abd al-Malik, Muḥammad b. Muḥammad al-Anșārī al-Awsī al-Marrākushī (2012), al-Dhayl wa-l-takmila li-kitābay al-Mawșūl wa-l-Șila, ed. by Bashshār 'Awwād, Iṇsān 'Abbās, and Muḥammad b. Sharīfa, 6 vols., Tunis: Dār al-Gharb al-Islāmī.

Ibn al-'Arabī, Abū Bakr al-Ishbīlī (2003), Aḥkām al-Qurāan, ed. by Muḥammad 'Abd al-Qādir 'Ațā, 14 vols., Beirut: Dār al-Kutub al-'Ilmiyya.

Ibn al-'Arabī, Abū Bakr al-Ishbīlī (1997), 'Ārị̣at al-aḥwadhī fĩ sharḥ al-Tirmidhī, ed. by Jamāl Mar'ashlī, 14 vols., Beirut: Dār al-Kutub al-'Ilmiyya.

Ibn al-'Arabī, Abū Bakr al-Ishbīlī (1992), Kitāb al-Qabas, ed. by Muḥammad 'Abd Allāh Wuld Karīm, Beirut: Dār al-Gharb al-Islāmī.

Ibn 'Asākir (1997), Ta'rīkh madinat Dimashq, ed. by Muḥibb al-Dīn al-'Amrawī, 80 vols., Beirut: Dār al-Fikr.

Ibn 'Ațā'illāh (1984), Kitāb al-Hikam, trans. by Victor Danner, Ibn 'Ațāillāh's Șūfí Aphorisms (Kitāb al-Ḥikam), Leiden: E. J. Brill.

Ibn al-Athīr, Abū al-Ḥasan 'Alī b. Muḥammad (1987), al-Kāmil fĩ al-ta'rīkh, ed. by Abū al-Fidā' alQāọī, 11 vols., Beirut: Dār al-Kutub al-'Ilmiyya.

Ibn 'Ațiyya al-Andalusī (1983), Fahrasat Ibn 'Ațiyya, ed. by Muḥammad al-Zāhī and Muḥammad Abū al-Ajfān, Beirut: Dār al-Gharb al-Islāmī.

Ibn Bashkuwāl, Khalaf b. 'Abd al-Malik al-Andalusī (2010), al-Șila fĩ ta'rīkh a'immat al-Andalus wa-'ulamāihim wa-muḥaddithīhim wa-fuqahāihim wa-udabāihim, ed. by Bashshār 'Awwād, 2 vols., Tunis: Dār al-Gharb al-Islāmī.

Ibn al-Faraḍī, Abū al-Walīd 'Abd Allāh (2008), Ta'rīkh 'ulamāa' al-Andalus, ed. by Bashshār 'Awwād Ma'rūf, 2 vols., Tunis: Dār al-Gharb al-Islāmī.

Ibn Farḥūn, Ibrāhīm b. 'Alī b. Muḥammad (1972), al-Dībāj al-mudhahhab fĩ ma'rifat 'ulamā’ almadhhab, ed. by Muḥammad al-Aḥmadī Abū al-Nūr, 2 vols., Cairo: Dār al-Turāth.

Ibn Ḥabīb, 'Abd al-Malik al-Sulamī al-Andalusī (2001), Tafsīr gharīb al-Muwatța', ed. by 'Abd alRaḥmān b. Sulaymān al-'Uțaymīn, 2 vols., Riyadh: Maktabat al-'Ubaykān.

Ibn Ḥajar al-'Asqalānī, Aḥmad b. 'Alī (1960), Faṭ̣ al-bārī, ed. by 'Abd al-'Azīz al-Bāz, 13 vols., Cairo: Dār al-Kutub al-Salafiyya.

Ibn Ḥawqal, Abū al-Qāsim (1992), Șūrat al-arḍ, Beirut: Dār al-Ḥayāt.

Ibn 'Idhārī, Abū al-'Abbās Aḥmad b. Muḥammad al-Marrākushī (2013), al-Bayān al-mughrib, ed. by Bashshār 'Awwād, 4 vols., Tunis: Dār al-Gharb al-Islāmī.

Ibn Khaldūn, 'Abd al-Raḥmān b. Muḥammad (2004), al-Muqaddima, ed. by 'Abd Allāh Darwīsh, 2 vols., Damascus: Dār Yu'rib.

Ibn Khaldūn, 'Abd al-Raḥmān b. Muḥammad (1958), al-Muqaddima, trans. by Franz Rosenthal, The Muqaddimah. An Introduction to History, 3 vols., New York: Pantheon Books.

Ibn Khallikān, Aḥmad Abū al-'Abbās (1978), Wafayāt al-a'yān wa-anbā'a abnā' al-zamān, ed. by lḥsān 'Abbās, 8 vols., Beirut: Dār Șādir.

Ibn Khayr, Abū Bakr Muḥammad al-Ishbīlī (1998), Fahrasat Ibn Khayr al-Ishbīlī, ed. by Muḥammad Fu'ād Manșūr, Beirut: Dār al-Kutub al-'Ilmiyya.

Ibn al-Najjār, Muḥibb al-Dīn al-Baghdādī (n.d.), Dhayl ta'rīkh Baghdād, 5 vols., Beirut: Dār alKitāb al-'Arabī.

Ibn al-Ṣalāḥ, Abū 'Amr 'Uthmān b. 'Abd al-Raḥmān Ṣalāḥ al-Dīn al-Kurdī (1984), Șiyānat Șaḥịh Muslim, ed. by Muwaffaq b. 'Abd Allāh b. 'Abd al-Qādir, Tunis: Dār al-Gharb al-Islāmī.

Ibn al-Ṣalāḥ, Abū 'Amr 'Uthmān b. 'Abd al-Raḥmān Șalāḥ al-Dīn al-Kurdī (1992), Ṭabaqāt fuqahā' al-shāfi'iyya, ed. by 'Alī Najīb, Beirut: Dār al-Nashr al-Islāmiyya.

Al-Idrīsī, Abū 'Abd Allāh Muḥammad (1989), Nuzhat al-mushtāq fì ikhtirāq al-āfāq, 2 vols., Beirut: 'Ālam al-Kutub. 
Al-'Irāqī, Zayn al-Dīn 'Abd al-Raḥīm (2006), al-Tabṣira wa-l-tadhkira, ed. by al-'Arabī al-Firyāṭī, Riyadh: Maktabat Dār al-Minhāj.

Al-Kattānī al-Fāsī (n.d.), Niz̄ām al-ḥukūma al-nabawiyya, ed. by 'Abd Allāh al-Khālidī, 2 vols., Beirut: Dār al-Arqam.

Al-Kattānī, Yūsuf (n.d.), Madrasat al-Imām al-Bukhārī fí al-Maghrib, 2 vols., Beirūt: Dār Lisān al-'Arab.

Al-Khațạābī, Abū Sulaymān b. Muḥammad (1988), Alām al-ḥadīth fí sharḥ Șaḥịh al-Bukhārī, ed. by Muḥammad b. Sa'īd Āl Sa'ūd, 2 vols., Mecca: Jāmi'at Umm al-Qurā.

Al-Maqqarī, Aḥmad b. Muḥammad (1978), Azhār al-riyāẹ fí akhbār Iyāọ, ed. by M. al-Saqqā, I. al-Abyārī, and 'A. Shalabī, 5 vols., Rabat: Mațba'at Faḍāa.

Al-Maqqarī, Aḥmad b. Muḥammad (1968), Nafh al-țīb min ghuṣn al-Andalus al-rațīb, ed. by lḥsān 'Abbās , 8 vols., Beirut: Dār Șādir.

Al-Māzarī, Abū 'Abd Allāh Muḥammad b. 'Alī al-Tamīmī (1988), al-Mu'lim bi-fawāìd Muslim, ed. by Muḥammad al-Shādhilī al-Nayfar, 3 vols., Tunis: Bayt al-Ḥikma.

Al-Mundhirī, Zakī al-Dīn al-Dimashqī (1987), Mukhtașar Șaḥị̣ Muslim, ed. by Muḥammad Nāṣir al-Dīn al-Albānī, Damascus: al-Maktab al-Islāmī.

Al-Nawawī (2000), al-Minhāj fĩ sharh Șaḥị̣ Muslim Ibn al-Ḥajjāj sharḥ al-Nawawī 'alā Muslim, Riyadh: Bayt al-Afkār al-Duwaliyya.

Al-Qābisī, Abū al-Ḥasan 'Alī (1986), al-Risāla al-mufașșala li-aḥwāl al-muta'allimīn wa-aḥkām al-mu'allimīn wa-l-muta'allimīn, ed. by Aḥmad Khālid, Tunis: al-Sharika al-Tūnisiyya li-lTawzī'.

Qāọī 'Iyāọ (1982), al-Ghunya, ed. by Māhir Zuhayr Jarrār, Beirut: Dār al-Gharb al-Islāmī.

Qāọī 'Iyāọ (1998), Ikmāl al-Mu'lim fĩ sharh Ṣaḥịh Muslim, ed. by Yaḥyā Ismā'īl, 9 vols., Mansoura: Dār al-Wafā’'

Qāọī 'lyāọ (1983), Tartīb al-madārik wa-taqrīb al-masālik li-ma'rifat álām madhhab Mālik, ed. by Muhammad b. Sharīfa et al., 8 vols., Rabat: Wizārat al-Awqāf wa-l-Shu'ūn al-Islāmiyya.

Al-Qasțalānī, Shihāb al-Dīn Aḥmad b. Muḥammad al-Khațīb (1905), Irshād al-sārī, 10 vols., Cairo: al-Mațba'a al-Amīriyya.

Al-Qurțubī, Abū al-'Abbās Aḥmad b. 'Umar b. Ibrāhīm (1980), al-Ilām bi-mā fĩ dīn al-nașārā min al-fasād wa-l-awhām, ed. by Aḥmad Ḥijāzī al-Saqqā, 3 vols., Cairo: Dār al-Turāth al-'Arabī.

Al-Qurțubī, Abū al-'Abbās Aḥmad b. 'Umar b. Ibrāhīm (1996), al-Mufhim li-mā ashkala min talkhīs kitāb Muslim, 7 vols., Damascus: Dār Ibn Kathīr.

Al-Ru'aynī, Abū al-Ḥasan 'Alī b. Muḥammad al-Ishbīlī (1962), Barnāmaj shuyūkh al-Ru'aynī, ed. by Ibrāhīm Shabbūḥ, Damascus: Maṭbū'āt Mudīiryyat lṇyā' al-Turāth al-Qadīm.

Al-Suyūțī, Jalāl al-Dīn (2013), Qūt al-mughtadhī 'alā Jāmi' al-Tirmidhī, ed. by Muḥammad b. Riyāọ al-Aḥmad, 4 vols., Beirut: Dār al-Kutub al-'Ilmiyya.

Al-Tujībī, al-Qāsim b. Yūsuf al-Sabtī (1981), Barnāmaj al-Tujībī, ed. by 'Abd al-Ḥāfiẓ Manșūr, Tunis: al-Dār al-'Arabiyya li-l-Kutub.

Al-Ya'murī, Abū al-Fatḥ Muḥammad b. Sayyid al-Nās (1989), al-Nafḥ al-shadhiyy fĩ sharh Jāmic al-Tirmidhī, ed. by Aḥmad Ma'bad 'Abd al-Karīm, Riyadh: Dār al-'Āṣima.

Yāqūt al-Ḥamawī (1988), Mujam al-buldān, 5 vols., Beirut: Dār Șādir. 


\section{Secondary sources}

Al-'Abbādī, Aḥmad Mukhtār (1978), Fì ta'rīkh al-Maghrib wa-l-Andalus, Beirut: Dār al-Nahḍa al'Arabiyya.

'Abd al-Wahhāb, Hasan H. (1955), al-Imām al-Māzarī, Tunis: Dār al-Kutub al-Sharqiyya. Āl Ḥumayyid, Sa'd (1999), Manāhij al-muḥaddithīn, Riyadh: Dār 'Ulūm al-Sunna.

Al-'Amad, Hānī S. (1993), Kutub al-tarājim wa-l-fahāris al-andalusiyya, Amman: Jordan University.

A'rāb, Sa 'īd (1987), Ma'a al-qāọī Abī Bakr Ibn al-'Arabī, Beirut: Dār al-Gharb al-Islāmī.

Al-A'ẓamī, Muḥammad Mușțafā (2000), Studies in Early Ḥadīth Literature, Kuala Lumpur: Islamic Book Trust.

Ben 'Ashūr, Yadh (1992), Politique, religion et droit dans le monde arabe, Tunis: Cérès Productions.

Blecher, Joel (2016), “Hadith Commentary”, Islamic Studies, Oxford Bibliographies 1-17, http://www.oxfordbibliographies.com/view/document/obo-9780195390155/obo9780195390155-0192.xml (accessed Jan. 13, 2019).

Brockelmann, Carl (1977), Tārīkh al-adab al-'arabī, trans. by 'Abd al-Ḥalīm al-Najjār, 6 vols., Cairo: Dār al-Ma'ārif.

Brockopp, Jonathan (2011), "Contradictory evidence and the exemplary scholar: the lives of Saḥnūn b Sa'īd (d. 854)”, International Journal of Middle East Studies 43/1, Cambridge: Cambrige University Press, 115-132.

Brown, Jonathan A. (2000), Hadith: Muhammad's Legacy in the Medieval and Modern World, Oxford: One World Publications.

Brown, Jonathan A. (2007), The Canonization of al-Bukhārī and Muslim, Leiden: Brill.

Brown, Jonathan A. (2011), "The Canonization of Ibn Mājah: Authenticity vs. Utility in the Formation of the Sunni Hadīth Canon", Écriture de l'histoire et processus de canonisation dans les premiers siècles de l'islam, REMMM 129, 169-181, https://journals.openedition.org/remmm/7154 (accessed Feb. 28, 2019).

Carmona, Alfonso (2005), “The Introduction of Mālik's Teachings in al-Andalus”, in: P. Bearman, R. Peters and F. E. Vogel, eds., The Islamic School of Law: Evolution, Devolution and Progress, Harvard - Cambridge: Harvard University Press, 41-56 and 218-227.

Chalmeta, Pedro (1994), Invasión e islamización. La sumisión de Hispania y la formación de AlAndalus, Madrid: Mapfre.

Cottart, Nicole, “Mālikiyya”, Encyclopédie de l'Islam, 2nd ed., 6: 263-268.

Dawrī, Muṣaddaq (2010), Riwāyat Șaḥịh Muslim min țarīq Ibn Māhān muqāranatan bi-riwāyat Ibn Sufyān, Tikrit: University of Tikrit.

Al-Dimashqī, Muḥammad Munīr (1988), Namūdhaj min al-a'māl al-khayriyya fĩ idārat al-țibāáa al-munīriyya, Riyadh: Maktabat al-Imām al-Shāfi ī.

Fierro, Maribel (1989), “The Introduction of ḥadith in al-Andalus (2nd/8th-3rd/9th centuries)", Der Islam 66, 68-93.

Fierro, Maribel (2011), “Local and global in Hadith literature: the case of al-Andalus”, in: Nicolet Boekhoff-van der Voort, Kees Versteegh and Joas Wagemakers, eds., The Transmission and Dynamics of the Textual Sources of Islam, Leiden: Brill, 63-90.

Fück, Johann (1938), "Beiträge zur Überlieferungsgeschichte von Buhārīs Traditionsammlung”, Zeitschrift der deutschen morgenländischen Gesellschaft 92, 60-87. 
Ghrab, Saad (1992), Ibn 'Arafa et le Malikisme en Ifriqiya au VIIIe-XIVe siècles, Tunis: Faculté des Lettres de La Manouba.

Guillaume, Alfred (1966), The Traditions of Islam, Beirut: Khayats.

Ḥajwī al-Tha'ālibī, Muḥammad (1926), al-Fikr al-sāmī fì ta’rīkh al-fiqh al-islāmī, Rabat: Idārat al-Ma'ārif.

Ibn Tāwīt, Muḥammad (1982), Tārīkh Sabta, Casablanca: Dār al-Thaqāfa.

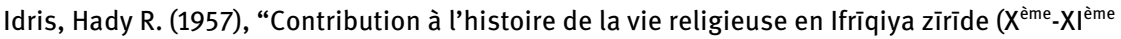
siècles)”, in: Mélanges Louis Massignon, Damascus: Institut français de Damas, 2: 327359.

Idris, Hady R. (1962), “L'école Malékite de Mahdia: l'Imām al-Māzarī”, in: Études d'orientalisme dédiées à la mémoire de Lévi-Provençal, Paris: G.-P. Maisonneuve et Larose, 1: 153-163.

Idris, Hady R. (1967), “Réflexions sur le Mālikisme sous les Umayyades d'Espagne”, in: Atti del 3o Congresso di Studi Arabi e Islamici (Ravello 1966), Naples, 397-414.

Al-Jabrānī, Ḥasan Ibrāhīm (2016), al-Rahalāt al-ilmiyya bayna Miṣr wa-l-Mashriq al-islāmī fĩ al'așr al-mamlūkī al-awwal, Amman: Dār Ghaydā'.

Al-Jīdī, 'Umar (1987), Muḥạ̣arāt fì ta'rīkh al-madhhab al-mālikī fĩ al-Maghrib al-islāmī, Casablanca: Manshūrāt 'Ukāẓ.

Kaddouri, Samir (2005), "Riḥalāt Aḥmad b. 'Umar al-Anșārī al-Qurțubī (t. 656 h.) fĩ al-Maghrib wa-l-Mashriq wa-mu'allafātuhu al-'ilmiyya”, Majallat Maktabat al-malik Fahd alwațaniyya 12/2, 160-207.

Al-Khalaf, 'Awwād (1923), Riwāyāt al-mudallisīn fị Șaḥịh Muslim, Beirut: Dār al-Bashā’ir alIslāmiyya.

Laqbāl, Mūsā (1951), al-Maghrib al-islāmī, Algiers: al-Sharika al-Wațaniyya li-l-Nashr wa-lTawzī‘.

Lévi-Provençal, Évariste (1923), “La recension maghribine du Șaḥịh d’al-Boḥārī”, Journal Asiatique 202, 210-233.

Lévi-Provençal, Évariste (1938), La Péninsule Ibérique au Moyen Âge, Leiden: Brill.

Lévi-Provençal, Évariste (1950-1955), Histoire de l'Espagne musulmane, 3 vols., Paris - Leiden: G.P. Maisonneuve - E.J. Brill.

López Lázaro, Fabio (2013), “The Rise and Global Significance of the First 'West': the Medieval Islamic Maghrib”, Journal of World History 24/2, 259-307.

Makhlūf, Muḥammad (1971), Shajarat al-nūr al-zakiyya fi țabaqāṭ al-mālikiyya, ed. by 'Abd alMajīd Khayyālī, 2 vols., Beirut: Dār al-Kutub al-'Ilmiyya.

Makkī, Maḥmūd 'Alī (1968), Ensayo sobre las aportaciones orientales en la España musulmana y su influencia en la formación de la cultura hispano-árabe, Madrid: Instituto de Estudios Islámicos.

Marín, Manuela (1985), "Ifriqiya et al-Andalus à propos de la transmission des sciences islamiques aux premiers siècles de l'Islam", Revue de l'Occident musulman et de la Méditerranée 40, 45-53.

Mawsū'at al-'ulamā' wa-l-udabā' al-jazāiriyyīn by various authors (2013), 2 vols., Bi'r al-Tūna: Manshūrāt al-Ḥaḍāra.

Mu'nis, Ḥusayn (2003), al-Maghrib wa-l-Andalus, Cairo: Dār al-Rashād.

Muranyi, Miklos (1997), Beiträge zur Geschichte der ḥadît-und Rechtsgelehrsamkeit der Mālikiyya in Nordafrika bis zum 5.Jh.D.H. Bio-bibliographische Notizen aus der Moscheebibliothek von Qairawān, Wiesbaden: Harrassowitz Verlag.

Needham, Joseph (1959), A History of Embryology, Cambridge: Cambridge University Press. 
Nūr al-Dīn, Ḥasan Ja'far (1989), Ibn Khafāja shāirir Sharq al-Andalus, Beirut: Dār al-Kutub al'Ilmiyya.

Nwīhị̣, ‘Ādil (1980), Mu'jam álām al-Jazā’ir, Beirut: Mu’assasat Nwīhiḍ al-Thaqāfiyya.

Puente, Cristina de la (1995), "Esclavitud y matrimonio en al-Mudawwana al-kubrā de Saḥnūn”, Al-Qanțara 16, 309-333.

Robson, James (1952), “The transmission of Abū Dāwūd's Sunan”, Bulletin of the School of Oriental and African Studies 14, 579-588.

Robson, James (1954), “The transmission of Tirmidhī’ Jāmi”, Bulletin of the School of Oriental and African Studies 16, 258-270.

Rustum, Zayn al-'Ābidīn (2005), "Ṣaḥị̣ al-Imām Muslim fī al-Andalus riwāya wa-dirāya”, AlHikma 29, 265-327.

Sa'dūn, Nașr Allāh (1988), Ta'rīkh al-'arab al-siyāsī fĩ al-Maghrib, Beirut: Dār al-Nahḍa al'Arabiyya.

Salmān, Ḥasan Mạ̣mūd (1994), al-Imām Muslim Ibn al-Hajjāj, Damascus: Dār al-Qalam.

Sánchez Albornoz, Claudio (1945), “Dónde y cuándo murió don Rodrigo, último rey de los godos", Cuadernos de Historia de España 3, 5-105.

Serrano Ruano, Delfina (2013), “Ibn Rushd al-Jadd (d. 520/1126)”, in: Oussama Arabi, David S. Powers and Susan A. Spectorsky, eds., Islamic Legal Thought: a Compendium of Muslim Jurists, Leiden - Boston: Brill, 295-322.

Sezgin, Fuat (1967), Geschichte des arabischen Schriffttums, 17 vols., Leiden: Brill.

Al-Sharīf, Nāṣir al-Dīn Muḥammad (1999), al-Jawāhir al-iklīliyya fĩ a'yān 'ulamā' Lībiyā min almālikiyya, Amman: Dār al-Bayāriq.

Șiddīqī, Muḥammad (1993), Hadīth Literature: Its Origin, Development and Special Features, Cambridge: The Islamic Texts Society.

Spies, Otto (1936), “Die Bibliotheken des Hidschas”, Zeitschrift der Deutschen Morgenländischen Gesellschaft 90 (n.F. 15), No. 1, 83-120.

Talīdī, Muḥammad (1995), Turāth al-maghāriba fĩ al-ḥadīth al-nabawī wa-ulūmihi, Beirut: Dār al-Bashā'ir al-Islāmiyya.

Trad, Khaoula (in press), “Muslim's Șaḥịh in the Islamic West: Chains of Transmission as an Object of Interest in the Commentary al-Mulim by al-Māzarī”, in: Hadith Commentary: Continuity and Change, Edinburgh: EUP.

Zaynahum, Muḥammad (1992), al-Imām Saḥnūn, Cairo: Dār al-Firjānī.

Ziriklī, Khayr al-Dīn (2002), al-A'lām, 8 vols., Beirut: Dār al-'Ilm li-l-Malāyīn. 